\title{
Sonho do passado versus plano para o futuro: gênero e representações acerca da esterilidade e do desejo por filhos*
}

\author{
Rosely Gomes Costa**
}

\begin{abstract}
Resumo
O texto traz uma discussão a respeito das representações sobre esterilidade e desejo por filhos entre homens que procuravam um ambulatório de reprodução humana em busca de informações e métodos de planejamento familiar ou em busca de tratamento para a esterilidade. Esses dados são comparados com os de uma pesquisa anterior com mulheres que procuravam o mesmo ambulatório em busca de tratamento para esterilidade. O texto mostra, entre outras coisas, como a esterilidade fere tanto a masculinidade quanto a feminilidade, ainda que de maneiras distintas. E como a paternidade é concebida como um plano para o futuro, que abriga a possibilidade de mudanças; enquanto a maternidade é concebida como a realização de um sonho desde sempre existente no passado feminino.
\end{abstract}

Palavras-chave: Paternidade, Masculinidade, Esterilidade, Gênero.

\footnotetext{
* Agradeço à prof ${ }^{a}$ Suely Kofes pelas discussões e comentários acerca das idéias aqui expostas; e também à FAPESP, pela bolsa de estudos que possibilitou a realização da pesquisa da qual originou este artigo. Recebido para publicação em agosto de 2001.

*** Professora recém-doutora junto ao Departamento de Antropologia Social IFCH/UNICAMP.
} 
Sonho do passado versus plano para o futuro

Past Dream Versus Future Plan

Gender and Representations of Sterility and Desire for Children

\begin{abstract}
The article discusses the representations of sterility and desire for children among men that go to a human reproduction ambulatory looking for family planning information and methods or looking for sterility treatment. These data are compared with those of another research with women that went to the same ambulatory looking for sterility treatment. The article shows, among other things, how the sterility hurts both masculinity and feminility, but in different ways. And how paternity is conceived as a plan for the future, that allows for the possibility of change; while maternity is conceived as the realization of a dream always existent in the feminine past.
\end{abstract}

Key words: Paternity, Masculinity, Sterility, Gender. 
Rosely Gomes Costa

\section{Introdução}

Reflexões a respeito da reprodução colocam questões instigantes em relação a gênero: como a esterilidade aparece afetando homens e mulheres? O desejo por filhos é igual entre homens e mulheres? Elaborando essas perguntas de uma perspectiva mais analítica de gênero: o que as percepções sobre masculinidades $e$ feminilidades revelam a respeito do desejo por filhos e sobre a impossibilidade de gerá-los? Este artigo visa desenvolver essas questões, que são discutidas em minha Tese de Doutorado. ${ }^{1} \mathrm{Na}$ pesquisa que resultou na tese, investiguei as concepções masculinas da paternidade e o que estas revelavam sobre a masculinidade e, de uma maneira mais ampla, sobre como gênero é constituído.

A pesquisa foi realizada em um ambulatório de reprodução humana de uma universidade paulista, com homens que estavam em busca de tratamento para esterilidade ou de orientação sobre planejamento familiar. Também foram colhidas informações com as enfermeiras, a assistente social e o médico responsável pelo ambulatório.

O ambulatório atende pessoas que estão procurando informações e métodos de planejamento familiar e aquelas que buscam tratamento para esterilidade. Qualquer que seja a procura, a pessoa é encaminhada para participar da "ação educativa", dada pelas enfermeiras. Essa ação consiste, no primeiro caso, em uma aula sobre os métodos anticoncepcionais disponíveis no ambulatório, as vantagens e desvantagens de cada um, e sobre o funcionamento dos aparelhos reprodutivos feminino $e$ masculino. No segundo caso, a ação educativa trata do funcionamento dos aparelhos reprodutivos feminino e masculino,

\footnotetext{
${ }^{1}$ CostA, R. G. Concepção de filhos, concepções de pai: algumas reflexões sobre reprodução e gênero. Tese de Doutorado em Ciências Sociais, IFCH, UNICAMP, 2001.
} 
Sonho do passado versus plano para o futuro

dos diferentes exames necessários para o tratamento da esterilidade e sobre as rotinas do tratamento.

Mas há uma diferença entre os casos de procura de tratamento para esterilidade e os de procura por informações $e$ métodos de planejamento familiar: o ambulatório exige a presença do marido/companheiro nos casos de solicitação de tratamento de esterilidade, o que não acontece no caso de busca por planejamento familiar. $\mathrm{O}$ ambulatório justifica a necessidade da presença do parceiro nos casos de tratamento para esterilidade da seguinte forma: para que ele não ache que o tratamento é fácil $e$ simples; para que não coloque a culpa na parceira caso ela não consiga engravidar; para que se submeta a exames de sangue $e$ ao espermograma ${ }^{2}$; e porque a esterilidade pode ser conjugal e, portanto, a participação do parceiro é fundamental para o tratamento. Quando a procura é por planejamento familiar, o parceiro só necessita ir ao ambulatório quando for solicitada uma laqueadura ou se deseja fazer vasectomia. Caso contrário, o parceiro não está obrigado a ir. Esta é uma diferença importante, que aparecerá referida nas reflexões propostas neste artigo.

Para a pesquisa foram entrevistados 21 homens. Destes, 12 foram ao ambulatório à procura de tratamento para esterilidade $e$ 9 foram à procura de planejamento familiar. A maioria tinha entre 26 e 35 anos de idade, afirmava ser branca, tinha o primário completo, estava empregada, recebia até seis salários mínimos ${ }^{3}$, era casada. A maioria das companheiras possuía o primário completo e não trabalhava fora de casa. A maioria dos homens tinha uma renda familiar total de até oito salários mínimos. Quatorze homens tinham filhos, sendo que entre os sete que não tinham está incluído um homem que teve um filho que morreu com dois dias de vida. Entre os 14 com filhos, nove homens

2 Exame que analisa a quantidade e qualidade do esperma.

3 Estou me baseando no salário mínimo dos meses de agosto e setembro de 1998 , correspondente a $\mathrm{R} \$ 120,00$. 
Rosely Gomes Costa

tinham 1 filho; dois tinham 2 filhos; dois tinham 3 filhos; e um tinha 5 filhos.

$\mathrm{Na}$ tese, assim como neste artigo, realizo um contraponto desta pesquisa com meu estudo anterior a respeito de concepções sobre maternidade com mulheres que procuravam tratamento para esterilidade neste mesmo ambulatório. Esse estudo resultou em minha Dissertação de Mestrado. ${ }^{4}$

\section{Esterilidade}

Ao se falar sobre o tema da esterilidade entre os entrevistados que estavam procurando tratamento para ter filho, a primeira reação destes foi dizer que o "problema" era com a companheira, não com eles. Os que já tinham o diagnóstico de que era a companheira que tinha dificuldade para engravidar ou para levar a gravidez a termo, logo esclareceram a questão. Os que não tinham o diagnóstico disseram que achavam que o "problema" era da companheira, justificando que em sua família não havia nenhum caso de esterilidade, ou dizendo que na família da companheira havia alguns casos. Romero, por exemplo, que tem uma filha, mas procura tratamento porque deseja outro filho $e$ a esposa não consegue engravidar, enfatiza que todos os seus irmãos têm filhos, com exceção de um. Mas esse irmão também já disse que o "problema" é com sua esposa, não com ele:

Bom, minha irmã que mora aqui em Campinas tem três, o outro não tem que casou agora pouco $e$ não tem ainda, talvez tenha que fazer tratamento também. Ele falou que é da parte da mulher, né? Agora o meu outro irmão tem um, tem uma irmã que tem dois e já está grávida de outro.

${ }^{4}$ CostA, R. G. Concepções sobre maternidade entre mulheres que buscam tratamento para esterilidade. Dissertação de Mestrado em Sociologia, IFCH, UNICAMP, 1995. 
Sonho do passado versus plano para o futuro

Apenas Joaquim disse que o "problema" era com ele. Afirmou que tomou a iniciativa de procurar o médico para ver se tinha algum problema quando a esposa não conseguiu engravidar, após o casal ter tomado a decisão de ter filhos. Enfatizou que achava que sua atitude não era corriqueira porque viu muitos homens que, durante a ação educativa dada pelas enfermeiras no ambulatório, ficaram apreensivos ao saber que eles também teriam que realizar exames em virtude do tratamento de esterilidade que estavam buscando.

A maioria dos entrevistados tinha a necessidade de contar uma história que explicasse a esterilidade, colocando na parceira e na família dela a sua causa, e indicando os filhos de irmãs $e$ irmãos como prova de sua própria fertilidade.

Colocar responsabilidades e culpas por problemas $e$ doenças na família do cônjuge pode ser uma prática comum, uma forma de preservar a imagem de sua própria família. Porém, no caso da esterilidade, alocar na parceira ou na sua família a origem do problema pode ser interpretado como uma forma de negar a possibilidade da esterilidade masculina pelo fato de ela estar freqüentemente associada à impotência sexual. As conversas que tive com as enfermeiras e com a assistente social confirmam que existe esta associação entre muitos homens que procuram o ambulatório. Segundo elas, essa representação é também um dos principais motivos que faz com que muitos homens resistam à idéia de se submeterem a uma vasectomia. Assim, a esterilidade pode ser vista por esses homens como colocando-os sob suspeita de impotência sexual. ${ }^{5}$

${ }^{5}$ Barbosa, em uma pesquisa com casais que buscavam uma gestação através das novas tecnologias reprodutivas, constatou que nos casos de infertilidade masculina, em regra, os maridos faziam com que as esposas assumissem socialmente o problema, uma vez que a ausência de filhos poderia pôr em questão sua masculinidade/virilidade. BARBOSA, R. M. Relações de gênero, infertilidade e novas tecnologias reprodutivas. Estudos Feministas, vol. 8, n ${ }^{\circ} 1$, 2000. 
Um caso específico pode servir para exemplificar a associação feita entre esterilidade e impotência sexual. Trata-se de um homem que contatei logo no primeiro dia de meu trabalho de campo, com o qual agendei uma entrevista, mas que não foi feita porque ele não compareceu. Ele estava procurando tratamento para esterilidade e, quando eu lhe disse que a entrevista era a respeito de sua opinião sobre ser pai, se ter filhos era bom ou não, começou a dizer que "estava na quarta mulher", que tinha quatro filhos com as outras parceiras, que a atual companheira tinha quatro filhos com o ex-marido, mas que nenhum vivia com ela $e$, portanto, ela queria ter um filho com ele. Sem que eu perguntasse mais nada, me disse que tinha 45 anos, que trabalhava há 12 anos como vigia noturno, mas que ainda era "muito fogoso", que a companheira anterior dizia para ele "procurar outras mulheres porque ela não dava conta". Mas que com a atual companheira ele se dava bem porque (com todo respeito por mim) fazia amor três vezes por dia com ela. Que, como era vigia noturno, fazia amor de dia com a companheira. Me perguntou se era normal a barriga da mulher ficar dura depois da relação sexual.

Portanto, ao escutar falar sobre filhos, a primeira referência feita por esse homem foi em relação às quatro companheiras que teve $e$ ao número de filhos que tem. Referiu-se à sua potência sexual - ao seu apetite sexual tão grande que a ex-parceira não conseguia "acompanhá-lo" -, e à freqüência de suas relações sexuais - apesar da idade e do trabalho noturno. Pode-se considerar então que a referência à paternidade para esse homem propiciou que ele fizesse associações com componentes como virilidade e potência sexual. ${ }^{6}$

Apesar de somente um entrevistado ter feito associação direta entre potência sexual e número de filhos, a rapidez em colocar a responsabilidade pela esterilidade na esposa/

${ }^{6}$ Fonseca também aponta a associação entre virilidade e fertilidade entre as famílias de classes populares de Porto Alegre, uma vez que se uma mulher recém-casada não engravida em seguida, surgem dúvidas a respeito da virilidade do marido. FonseCA, C. Os caminhos da adoção. São Paulo, Cortez, 1995. 
Sonho do passado versus plano para o futuro

companheira parece indicar que a associação entre impotência sexual e esterilidade também faz parte das representações destes entrevistados.

Pelo fato de que para os entrevistados o casamento pressupõe filhos ("quem casa quer filhos", "um casal sozinho é muito triste"), e porque, com exceção de Joaquim, os demais entrevistados que estavam procurando tratamento para esterilidade consideravam que o "problema" era da parceira, falar sobre esterilidade fez surgir a questão de permanecer com a companheira que não consegue tê-los ou procurar outra mulher para tê-los. Osvaldo disse que seus exames deram normal, isto é, ele pode ter filhos, sua esposa é que não pode. Como não é obcecado por ter filho, diz que não se separa da esposa, nem tem filho com outra mulher:

Foi ela que começou a procurar, ela que marcava os médicos, ela que fazia tudo isso. Então, questão obrigatoriamente assim, taxativa, ou tem filho ou separa, ou tem filho ou vou com outra, não tinha. Porque todos meus exames deram normal. Então, quer dizer, se eu fosse obcecado por um filho, me separaria dela ou teria uma vida paralela e teria um filho tranqüilo.

Osvaldo enfatizava que queria um filho, mas que não era obcecado por isso, que não sentia desespero por não ter filho, como era o caso de sua esposa. Entretanto, trouxe a idéia de que considera a esterilidade da parceira como um motivo para abandoná-la, ou para ter uma vida paralela, caso fosse "obcecado" por ter um filho. Algumas entrevistadas de minha pesquisa anterior também se referiram ao medo de serem abandonadas caso não conseguissem "dar filhos" aos maridos/ companheiros.

Por outro lado, Sérgio também levantou a questão de a mulher procurar outro homem quando o marido é estéril. Sérgio, cuja esposa está fazendo tratamento para abortos recorrentes, referiu-se às brigas e desconfianças que surgem entre o casal nos 
casos de esterilidade masculina. Segundo ele, o marido desconfia que a esposa irá procurar outro homem para conseguir engravidar:

A gente se sente só. Também dá muita briga no casal, eu sei porque já aconteceu comigo. (...) Tem muita desconfiança. (...) Que quando eu... no meu pensar, quando a mulher aparece grávida dele, ele pensa que não é dele.

Antes dos abortos espontâneos, a esposa de Sérgio teve dificuldade de engravidar. Quando engravidou, Sérgio desconfiou que o filho podia não ser dele. Até que fez os exames e descobriu que o "problema" era com a esposa. Assim, também a esterilidade masculina foi vista como motivo para abandonar o marido ou procurar outro homem para ter filho.

Ao mesmo tempo em que estes entrevistados procuravam esclarecer que o "problema" de esterilidade era da esposa/ companheira e não deles próprios, buscavam também minimizar a importância, o "problema" da esterilidade masculina. Quando perguntei como se sentiria se soubesse que não podia gerar filhos porque tinha algum problema, Romero respondeu que:

Eu ficaria chateado, aí eu ia querer saber por que e ia fazer tratamento também. Acho que a gente fica um pouco chateado, né? Porque a mulher também fica. Igual meu cunhado, ele não pode ter filho não, porque ele teve leucemia, sabe? Aí ele... acho que ele nem esquenta, sei lá, só que ele queria ter filho, mas falaram que ele não pode não.

Essa minimização pode ser percebida nos termos usados pelos entrevistados para se referirem aos sentimentos dos homens $e$ das mulheres em relação a não poder ter filhos. Quando perguntados como se sentiriam se soubessem que eram estéreis, disseram que se sentiriam tristes, chateados, frustrados; mas que 
Sonho do passado versus plano para o futuro

encarariam o problema, o superariam. Mas suas esposas/ companheiras se soubessem que eram estéreis (ou quando souberam que o "problema" em não conseguir engravidar era delas) ficariam (ou ficaram) desesperadas, com medo de serem abandonadas, traumatizadas.

Osvaldo, após reafirmar que o "problema" era da esposa $e$ que na família dela havia casos de esterilidade, considerou que:

Eu? Primeiro eu já fui em vários lugares e todos já disseram que eu posso, certo? (...) Na minha família não tem caso de esterilidade ou anormalidade nessa área, e na dela já tem. (...) No começo, antes de fazer os exames, eu me perguntava: e se o problema for meu? Eu acho que eu ficaria pensando nisso um pouco, mas não seria um trauma permanente na minha vida. Uma coisa que daria pra gente trabalhar em cima e superar. Não seria um trauma permanente que atingiria minha vida sexual, profissional, minha vida familiar. (...) A minha mulher no começo ficava muito desesperada, ficava num estado de nervo: eu não posso ter filho, eu quero ter um filho.

Pedro considerou que ele encararia melhor que a esposa o fato de não poder ter filhos:

Acho que tudo bem, acho que ia encarar isso de forma natural, isso daí acontece. Eu acho que ela ia sentir um pouco sim, porque acho que ela ia ficar mais frustrada de não poder ser mãe assim de um jeito natural.

No caso dos entrevistados que tinham filhos, perguntei como se sentiriam se soubessem que não podiam ter filhos. Alguns disseram que não saberiam responder, uma vez que, como tinham filhos, nunca haviam pensado nisso. Outros disseram que se sentiriam tristes, chateados; e também relataram que seria pior para a esposa que para eles. 
A noção de desespero foi referência constante por parte dos entrevistados quando falavam a respeito da reação de suas parceiras em caso de não conseguirem ter filhos. Eles consideraram que as parceiras ficariam (ou ficaram) desesperadas se soubessem (quando souberam) que tinham problema para ter filhos; ao passo que a esterilidade masculina foi colocada de forma menos dramática, como uma questão que seria encarada $e$ superada. Esta noção de desespero referia-se a crises de choro, à busca intensiva para a solução do problema da esterilidade, a referências diretas à sensação de desespero por não conseguir ter filho. Há, por parte dos entrevistados, uma ênfase muito grande a respeito do desespero feminino diante da impossibilidade de ter filho. Os entrevistados marcam a noção de desespero como parte da reação das mulheres à esterilidade. Entretanto, a necessidade de esclarecer prontamente que o "problema" era da parceira e a negação da possibilidade da própria esterilidade indica que a esterilidade masculina não é encarada de uma forma tão tranqüila quanto os entrevistados desejam fazer transparecer. Porém, a manifestação legítima do desespero em relação à esterilidade aparece alocada nas mulheres.

Também as entrevistadas de minha pesquisa anterior utilizavam essa noção de desespero quando se referiam à esterilidade feminina, e tratavam a esterilidade masculina de forma mais amena. Portanto, as representações dos entrevistados e entrevistadas sobre a reação das pessoas diante da incapacidade de ter filhos está marcada pelo gênero, sendo o desespero $e$ a legitimidade de sua manifestação alocados nas mulheres; e a tristeza, a legitimidade de sua manifestação e a superação alocadas nos homens.

Em relação à capacidade de "fazer filhos", Eduardo (que procurava tratamento para esterilidade), após dizer que o "problema" era da esposa, relatou que seu pai tinha tido nove filhos. Quando perguntei quantos filhos gostaria de ter, ele disse que gostaria de ter até 20. Enfatizou, ainda, que se o "problema" fosse com ele, ele se sentiria normal, mas que já havia feito o 
Sonho do passado versus plano para o futuro

exame e estava tudo bem, ele podia ter filhos: "Eu também já fiz exame pra ver se podia, o meu deu positivo, deu até demais".

Ao falar "deu até demais", Eduardo estava se referindo à quantidade de espermatozóides encontrados através do espermograma. Eduardo parece acreditar que a maior quantidade de espermatozóides significa maior fertilidade. ${ }^{7}$

Ao se referir aos nove filhos que havia tido o pai e à sua própria "normalidade" para ter filhos, Eduardo parece estar marcando a fertilidade como atributo da masculinidade presente no pai $e$ herdada por ele. Uma fertilidade traduzida em quantidade, demonstrando capacidade: número de filhos que teve o pai, número de filhos que deseja ter, número de espermatozóides encontrados através de seu espermograma. A fertilidade como atributo da masculinidade aparece assim marcada pela capacidade de fazer filhos, pela potência sexual, pela virilidade, força, saúde e vigor.

Por outro lado, Marcos, que também estava procurando tratamento para esterilidade, enfatizou que a capacidade de "fazer um filho" não é suficiente para constituir um pai:

Porque o filho, não é só fazer. Eu chego na minha terra lá eu fico bobo de ver os meus colegas: três, quatro. Eu falo pô, fazer todo mundo faz, eu quero ver educar, dar uma boa alimentação, um bom estudo, é meio complicado.

Marcos estabelece uma conexão diferente entre paternidade e masculinidade. "Fazer filho" todo mundo faz. O que distingue um pai é a capacidade de prover e educar os filhos. Sua concepção de paternidade refere-se antes à capacidade de

\footnotetext{
7 O que não é necessariamente verdadeiro, pois, de acordo com a enfermeira que trabalha no ambulatório, ter grande número de espermatozóides não significa fertilidade. Isto porque os espermatozóides podem ser muitos, mas não ter a motilidade necessária à fecundação, podem estar mortos, ou apresentar algum outro tipo de defeito. Isto é, a quantidade de espermatozóides não garante sua qualidade.
} 
trabalho (que garante o sustento material e a educação dos filhos), que à capacidade física da fertilidade.

Eduardo e Marcos dão interpretações diferentes para a capacidade de "fazer filhos": Eduardo a considera como instituidora da masculinidade, enquanto que para Marcos é condição necessária, mas não suficiente para esta instituição, colocando na capacidade de sustentar e educar os filhos a distinção da masculinidade. Assim, a fertilidade pode ser interpretada como prova de masculinidade ou como condição necessária, mas não suficiente de masculinidade, que depende ainda da capacidade de criar os filhos gerados.

Esta última noção também foi encontrada por Jardim em seu estudo com homens de baixa renda freqüentadores de bares (botecos) em Porto Alegre. Entre eles também está presente a idéia de que qualquer um pode "fazer filhos", mas não conseguir provê-los pode significar perda do respeito e do status social que o homem adquiriu ao tornar-se pai:

Nas conversas entre homens, esta posição social "irreversível" conferida pela paternidade trazia junto a polêmica: todo o homem "faz filho", mas a capacidade de o homem provê-los é fundamental, uma situação que apresenta mais claramente uma série de dilemas específicos em torno da condição de provedor. Fazer filhos e ser provedor indicavam a referência à capacidade "de todo o homem" de usar o corpo, porém aquela que confere uma posição social e um valor social é a do provedor, pois estabelece uma posição do sujeito nas redes familiares. ${ }^{8}$

Dois pontos levantados por alguns entrevistados que procuravam tratamento para esterilidade, e não citados por nenhuma das entrevistadas anteriormente, dizem respeito ao

8 JARDIM, D. F. Performances, reprodução e produção dos corpos masculinos. In: LeAL, O. (org.) Corpo e Significado. Ensaios de Antropologia Social. Porto Alegre, Editora da UFRGS, 1995, pp.198-199. 
Sonho do passado versus plano para o futuro

problema de ter que faltar do trabalho nos dias que necessitavam ir ao ambulatório; e aos gastos que tinham com o tratamento. Sérgio, que trabalha como servente de pedreiro e tem uma renda familiar em torno de 3 salários mínimos, explicou que:

Porque se o tratamento fosse lá na minha cidade ficaria barato pra gente. Mas que nem aqui em Campinas, eu ganho pouco, então é meio difícil. Sai tudo do meu bolso, não ganho nada de prefeito, nada da cidade, tudo do meu bolso e o que eu ganho é pouco pra isso. Que nem agora, está saindo muito remédio, passagem, despesa de casa, aluguel de casa, e só eu que trabalho. Quando venho aqui eu perco o dia de serviço. Às vezes, o dia que eu perco eu reponho no sábado. Mas aí é quando o patrão quer, quando ele não quer não tem jeito.

Eduardo, que trabalha como operador de máquina e tem uma renda familiar de 7,5 salários mínimos, disse que:

Se o problema fosse comigo eu faria o tratamento. Depende de estar ao meu alcance, porque não dá pra faltar no serviço direto. Tem que ir controlando, num dia de folga vai lá e faz o tratamento, no dia de serviço tem que estar lá, o serviço que eu faço eu não posso faltar.

Sérgio e Eduardo parecem considerar que as mulheres não têm nenhum problema de tempo para ir até o ambulatório fazer o tratamento, apesar de a esposa de Eduardo trabalhar fora de casa. Essa idéia parece estar informada pela concepção que os entrevistados têm de que cabe ao homem trabalhar para sustentar a familia, enquanto à mulher cabe a responsabilidade pelos filhos, inclusive a de conseguir tê-los ou de evitá-los. Assim, mesmo se a mulher trabalha fora de casa, parece que se considera mais tolerável que ela falte ao trabalho para ir ao tratamento médico.

Por seu lado, o ambulatório fornece atestado para ser apresentado como justificativa de falta ao trabalho para as 
mulheres que procuram tratamento para esterilidade ou o planejamento familiar. Porém, para os homens, o atestado só é fornecido para os que procuram tratamento para esterilidade, porque nesse caso os homens são obrigados a comparecer no ambulatório. O médico responsável pelo ambulatório disse que achava que os homens também deveriam participar da ação educativa sobre planejamento familiar oferecida pelo ambulatório, mas que eles não podem porque estão trabalhando. Disse que na ação educativa e primeira consulta de esterilidade (das quais são obrigados a participar), os homens podem obter um atestado médico para justificar sua falta no trabalho, pois a esterilidade é considerada uma doença. Já a procura por métodos anticoncepcionais não serve como argumento no trabalho para justificar uma falta por parte dos homens.

Assim, o ambulatório justifica a não-obrigatoriedade dos homens em assistirem à ação educativa sobre planejamento familiar com base no fato de que eles não teriam como justificar sua falta no trabalho; embora o próprio ambulatório não ofereça o atestado nesses casos porque a presença do homem não é obrigatória. Por outro lado, as mulheres podem obter atestados nos dois casos, o que pode ser interpretado como sinal de que sua presença é obrigatória em ambos os casos ou, a dar crédito às palavras do médico, que a procura por métodos anticoncepcionais serve como argumento no trabalho para justificar uma falta apenas no caso das mulheres. Esses fatos parecem indicar a cristalização no nível institucional de uma representação que atribui às mulheres a responsabilidade pela saúde reprodutiva $e$ aos homens a responsabilidade pelo sustento do lar, representado pelo trabalho remunerado fora de casa.

Considero que estas atribuições podem servir para explicar a alocação do desespero nas mulheres, quando não conseguem ter filhos; e porque os entrevistados (e não as entrevistadas) se preocuparam com a falta no trabalho e com os gastos relativos ao tratamento. Pois, se a responsabilidade feminina relaciona-se a ter filhos, as mulheres expressam maior "desespero" ao não conseguir 
Sonho do passado versus plano para o futuro

tê-los, e minimizam problemas em relação a tempo e gastos, nem chegando mesmo a citá-los, mesmo que trabalhassem fora de casa ou que não tivessem boas condições financeiras. Já os entrevistados, minimizavam a questão da esterilidade ao sublinhar os problemas de falta de tempo e de gastos financeiros, já que a responsabilidade masculina refere-se ao trabalho e ao sustento da casa.

A questão da esterilidade aponta para outra distinção de gênero. A esterilidade mostrou ser um problema que fere tanto a masculinidade quanto a feminilidade, mas de maneira distinta. Pesquisas apontam o bom desempenho sexual, a tomada de iniciativa e a ação sexual (em oposição à passividade) como elementos constituintes da masculinidade. ${ }^{9}$ Para os homens, sexualidade e reprodução estão associadas de uma maneira que não encontra similaridade entre as mulheres. Isto é, a excitação sexual e o orgasmo são considerados necessários para a participação reprodutiva dos homens e irrelevantes para a participação reprodutiva das mulheres. Assim, a esterilidade masculina pode estar associada à impotência sexual e pode ameaçar a virilidade. Como para as mulheres não há associação entre fertilidade e sexualidade (a gravidez independe da excitação sexual e do orgasmo ${ }^{10}$ ), não conseguir ter filhos não ameaça sua sexualidade, mas coloca em questão sua feminilidade, porque as impede de cumprir sua vocação feminina "natural" de mãe.

As entrevistadas de minha pesquisa anterior enfatizavam a maternidade como um desejo e um evento naturais na vida das mulheres, como um sonho de toda mulher, como parte da essência feminina. Os entrevistados não se referiram ao instinto

9 PARKER, R. \& BARBOSA, R. M. Sexualidades Brasileiras. Rio de Janeiro, Relume Dumará, 1996; HeIlborn, M. L. A primeira vez nunca se esquece. Estudos Feministas, vol. 6, n 2, 1998.

${ }^{10}$ Segundo Laqueur, esta representação é recente, pois, até o século XVIII, a ciência médica considerava necessários para a concepção tanto o orgasmo masculino quanto o feminino. LAQUEUR, T. La construcción del sexo. Cuerpo y género desde los griegos hasta Freud. Madrid, Ediciones Cátedra, 1994. 
masculino ou à natureza masculina para justificar seu desejo por um filho. As opiniões convergiram no sentido de que as entrevistadas também não concebiam o desejo pela paternidade como uma essência masculina; e os entrevistados também consideravam o desejo pela maternidade como parte da essência feminina.

A pesquisa com os homens mostrou que a paternidade é atribuição da masculinidade, mas não da mesma forma que a maternidade é atribuição da feminilidade. Pois a maternidade era vista pelas entrevistadas de minha pesquisa anterior como um desejo que sempre existiu, como natural, instintivo, essencial, como a realização de um sonho do passado. Desta forma, pareceme que a representação é a de que as mulheres vão constituindose mães ao longo de suas trajetórias de vida, e que a maternidade é uma experiência de continuidade, de repetição, de realização de um plano desde sempre elaborado no passado feminino. Seria uma perspectiva do passado que se atualiza em cada mulher no presente.

Os homens concebem a paternidade como um desejo que se estabelece em um determinado momento de suas trajetórias de vida - o casamento -, um desejo que amadurece com o tempo e que está voltado para o futuro, para a descendência. A paternidade é um projeto para o futuro, enquanto a maternidade aparece como uma continuidade. A paternidade instaura uma nova condição de homem adulto, provedor, enquanto a maternidade resgata uma condição feminina essencial desde sempre existente.

Se, como argumentei acima, a paternidade é concebida como um projeto para o futuro $e$ a maternidade como realização de um plano desde sempre elaborado no passado feminino, a referência ao maior desespero experimentado pelas mulheres ao não conseguirem ter filhos também pode ser vista como advinda da impossibilidade de mudança do plano da maternidade, localizada na continuidade; em oposição à possibilidade de mudança do projeto futuro de paternidade. Isto é, como a 
Sonho do passado versus plano para o futuro

paternidade é concebida como um projeto para o futuro, ela abriga a possibilidade de mudança deste projeto, permite a existência de alternativas, que podem fazer com que a sensação de desespero não seja tão marcada. Alternativas que não se apresentam no caso da maternidade, uma vez que é concebida como uma repetição, uma continuação, cuja quebra coloca em questão a feminilidade essencial que a maternidade reafirma.

Além disso, mesmo que a esterilidade masculina ameace a masculinidade devido a sua associação com a impotência, esta ameaça pode ser afastada por provas de potência sexual; enquanto a ameaça da esterilidade à feminilidade só pode ser afastada através da maternidade.

Portanto, o fato de a esterilidade ter estado referida principalmente às mulheres, assim como o desespero por não conseguir ter filhos - presente tanto entre as entrevistadas quanto entre os entrevistados - aparece associado a uma representação de feminilidade atrelada à maternidade.

\section{Importância de ter filhos para homens e mulheres}

Como referido anteriormente, os entrevistados colocaram seu desejo por filhos como estabelecido pelo casamento, e não como um desejo natural que sempre existiu. Eles consideravam que as mulheres são mais "obcecadas" por terem filhos, e se sentem "desesperadas" quando não conseguem. Alguns entrevistados que tinham filhos disseram que se soubessem que eram estéreis aceitariam a situação, a superariam ou tentariam adotar uma criança; mas que suas mulheres sofreriam muito, porque o desejo de toda mulher é ter um filho. Os que estavam procurando tratamento para esterilidade também compartilhavam dessa opinião. Alguns disseram que queriam muito ter um filho, mas sempre considerando a mulher como mais desejosa de um filho do que eles.

Antônio, que tem um casal de filhos e cria o filho que a esposa teve com outro homem, disse que se não pudesse ter 
filhos, adotaria uma criança para "compensar" o problema. Já sua esposa, ele acha que sofreria muito: "Eu acho que ela sofreria muito porque o sonho, acho, da mulher é casar de véu e grinalda na igreja, e ter filhos. Eu acho que é o sonho, então acho que ela sofreria bastante".

Osvaldo, que cria a filha da irmã e procurava tratamento para esterilidade, foi um pouco mais longe e relacionou a maior necessidade das mulheres em ter filhos com a educação que elas recebem e com a pressão social:

Eu acho que vem do ambiente familiar ou da própria sociedade, do próprio convívio social. Se você é criado para casar e ter filhos, você vai ter na sua cabeça, psicologicamente, trabalhar assim e viver assim. Vou crescer, com 15 anos eu caso, 18, com 20 eu tenho um filho. De repente com 20 não pode ter filho, aí desmorona toda aquela filosofia de vida. Aí a pessoa se sente impotente. Eu acho que a pessoa tem uma psicologia bem danificada.

Ao colocar na educação orientada para ter filhos a razão pelo maior desejo das mulheres de tê-los, Osvaldo relativizou percepções, muitas vezes essencialistas, apresentadas pelos demais entrevistados sobre o desejo natural das mulheres pela maternidade.

Miguel, que tem uma filha pequena, disse que se sentiria "um lixo" se soubesse que não podia ter filhos e que adotaria uma criança. Mas considera, assim como Osvaldo, que para a mulher é pior que para o homem não poder ter filhos, porque a mulher é criada para isso. Em outro momento da entrevista, Miguel disse que foi criado para ter filhos, mas no momento dessa argumentação diz que o homem não é tão cobrado pela sociedade - como a mulher - para ter filhos, porque sua função é trabalhar e prover a casa, já a função esperada da mulher é a de ser mãe. Entretanto, após referir-se à importância da educação $e$ da pressão social em relação ao desejo de ter filhos - não 
Sonho do passado versus plano para o futuro

associando o maior desejo das mulheres por filhos a uma natureza feminina -, Miguel finalizou dizendo que a mulher "por si só já é mais sentimental". Assim, seu pensamento parece ter dado uma volta completa para se fechar na idéia de que a socialização tem um peso importante no fato de as mulheres desejarem mais que os homens ter filhos; mas que a mulher é criada dessa maneira justamente porque é naturalmente mais sentimental.

$\mathrm{Na}$ nossa sociedade há vários discursos a respeito de gênero. São discursos heterogêneos e, às vezes, contraditórios, que concorrem entre si pela hegemonia, como é o caso de discursos baseados em noções de socialização e discursos baseados em noções essencialistas. Parece-me que a argumentação de Miguel mostra justamente uma tentativa de justaposição desses discursos, no intuito de abarcá-los em uma síntese dotada de sentido para ele.

Carlos, apesar de enfatizar ao longo da entrevista a paixão que tem pelos dois filhos, considerou que, de uma maneira geral, as mulheres querem mais que os homens ter filhos:

Eu acho que as mulheres gostam mais... Elas querem mais, não gostam, querem mais filho do que homem. A mulher ela é capaz de qualquer coisa por um filho, o homem já não, ele... têm alguns que sim, outros que não, mas se você for jogar isso na média, a média vai dar bem baixa.

Arilha considera que:

Mulheres desejam o filho, homens desejam a família. A idéia/desejo/vontade/aspiração de ser pai viria com a maturidade e com o casamento, ao contrário do que parece ocorrer com muitas mulheres que ainda necessitam do filho para determinar sua feminilidade. ${ }^{11}$

${ }^{11}$ ARILHA, M. Homens: entre a "zoeira" e a "responsabilidade". In: ARILHA, M.; Ridenti, S.; Medrado, B. (orgs.) Homens e masculinidades. Outras palavras. São Paulo, ECOS/Editora 34, 1998, p.60. 
Essa idéia não só está de acordo com a percepção que os entrevistados manifestaram sobre o maior desejo por parte das mulheres de ter filhos, como também com a representação que encontrei entre as entrevistadas de minha pesquisa anterior, que associava maternidade e feminilidade.

Os entrevistados consideravam que a gravidez é a responsável por estabelecer uma ligação muito forte entre a mãe e a criança, o que não ocorre no caso do pai. Carlos, mesmo com a grande ligação que disse ter com os filhos, considera que:

Acho que mãe ela tem um privilégio maior que o pai. Acho que um filho abandonaria um pai, e não abandonaria a mãe, por maior que fosse o desgosto que ela talvez desse a ele. É aquela ligação materna, ela tem uma ligação maior. O filho quando está sendo gerado ele está ligado diretamente ao corpo da mãe. Já com o pai não, o pai simplesmente foi uma sementinha, mas ele foi germinado na mãe, ali ela ficou grudada, então ele é um pedaço a mais da mãe. O pai eu acho que ele está mais só na feição, o aspecto da fisionomia, mas a ligação realmente é da mãe.

Alfredo relatou ter uma relação muito próxima com os três filhos - "vivia para os filhos" - e considerou que "filho é coisa de dentro da gente". Foi o único entrevistado que fez referência a uma representação corpórea da paternidade, os demais associaram a corporalidade à gravidez e à maternidade.

A idéia de que a mulher tem uma ligação mais forte com o filho por causa da gravidez parece estar associada à idéia de que por isso ela também tem mais vontade de ter filhos, que tem um desejo natural pela maternidade. O desejo pela paternidade é concebido como vindo com o casamento e se concretizaria não só na capacidade reprodutiva, mas na capacidade de educar $e$ sustentar a criança. Arilha concluiu de sua pesquisa que: 
Sonho do passado versus plano para o futuro

"Conviver e assumir a 'responsabilidade' dão o sentido da paternidade, e não a reprodução biológica em si." 12

Entretanto, se o desejo de ter filhos por parte dos entrevistados veio com o casamento, não creio que se possa considerar que a reprodução biológica não dá sentido à paternidade. Ela pode não ser suficiente - como ressalta a fala de Marcos apresentada na seção anterior - mas, uma vez que o entrevistado tenha manifestado o desejo por filhos, esse desejo se expressa em filhos que sejam "seus", "próprios", de "seu sangue". Isso pode ser observado nas entrevistas, ou pode ser deduzido do fato de alguns entrevistados estarem procurando tratamento para esterilidade mesmo depois de terem adotado uma criança ou de estarem criando os filhos da esposa.

Considero que está presente entre os entrevistados uma representação de paternidade que engloba tanto a capacidade de sustentar e educar os filhos, quanto a capacidade de "fazer filhos". Isto é, não há uma desconsideração da parte biológica da paternidade. $\mathrm{O}$ homem se constitui pai a partir do nascimento do filho, mas considera-se que foi seu esperma que deu origem à possibilidade dessa constituição.

Segundo Laqueur, a paternidade e a maternidade se constituem na relação emocional, na união intensa e profunda com o filho, nascido ou não. Sem deixar de colocar que: "Las mujeres tienen demandas respecto del bebé que llevan dentro simplemente en virtud de sus relaciones espaciales com él y tienen derecho a la integridad corporal"13, Laqueur considera que a gravidez não faz com que automática e necessariamente a mulher se sinta unida ao bebê, não considera que esses sentimentos venham da "carne":

${ }^{12}$ ID., BB., p.66.

${ }^{13}$ Laqueur, T. Los hechos de la paternidad. Debate Feminista, ano 3, vol. 6, 1992, p.139. 
Rosely Gomes Costa

El "hecho" de la maternidad es precisamente el trabajo psíquico que hay que realizar para hacer esas conexiones (emocionales $e$ imaginativas), para apropiarse del feto $y$ luego de la criatura dentro de la economia moral y emocional de la madre. El "hecho" de la paternidad es de un orden semejante. ${ }^{14}$

Se, para o autor, a gravidez não gera automaticamente essa ligação, não é a sua ausência no corpo masculino que impede que ela seja criada por parte do homem. Mas tampouco essa criação surge do nada, ela surge da idéia de que foi seu esperma que fecundou aquela mulher, que é uma parte de si que está ali. Portanto, as demandas de paternidade e maternidade surgem:

(...) de una unión intensa y profunda com la criatura, nacida o no, que el parentesco biológico debe encender en la imaginación moral y afectiva, pero no necesariamente sujeta al vínculo material. ${ }^{15}$

Portanto, podemos considerar que se essa união não surge, não importa para o "fato" da paternidade que tenha havido vínculo material. Ou seja, não é porque uma mulher engravidou com o esperma de um determinado homem que ele será considerado o pai da criança, como demonstram os bancos de esperma ou a opinião de alguns entrevistados de que se o homem não deseja o filho (quando perguntados em relação ao aborto voluntário) ele deve ir embora e abandonar a parceira. Por outro lado, essa união com a criança não está necessariamente sujeita ao vínculo material, como demonstram os casos de adoção ou de criação dos filhos da parceira.

\footnotetext{
${ }^{14}$ ID., IB., p. 130.

${ }^{15}$ ID., IB., p.141.
} 
Sonho do passado versus plano para o futuro

Strathern ${ }^{16}$ entende por parentesco não somente as maneiras como os parentes interagem, mas também como pensam que essas relações se constituem. A autora considera que, na representação denominada por ela de euro-americana, parentesco é um conceito híbrido, uma vez que este é considerado como um fato da sociedade enraizado em fatos da natureza. Nesta representação, ter relações sexuais, transmitir genes e dar à luz são fatos da vida que foram tomados como base para as relações entre esposos, irmãos, pais e filhos; os quais foram, por sua vez, tomados como a base das relações de parentesco. As pessoas reconhecidas como parentes são aquelas relacionadas pelo sangue $e$ as relacionadas pelo casamento, isto é, são aquelas que resultaram da procriação ou de uma perspectiva de procriação. $\mathrm{O}$ processo de procriação como tal é visto como pertencendo ao domínio da natureza, e não ao domínio da sociedade. Por outro, o parentesco é visto como um arranjo social dos fatos naturais, conectando assim os dois domínios.

A vida familiar, por exemplo, é considerada como residindo em dois princípios separados. De um lado, ela reside no caráter social de arranjos particulares, como a composição familiar, a extensão das redes de parentesco ou as convenções do casamento, que são variáveis sociais. Por outro lado, reside nos fatos naturais da vida como nascimento e procriação, herança de material genético, estágios de desenvolvimento através dos quais a criança progride, que são naturalmente imutáveis. Portanto, falar em parentesco é referir-se à maneira pela qual os arranjos sociais estão baseados em processos naturais, e em como estes provêem o contexto cultural. O parentesco é considerado como uma construção social de fatos naturais, sendo que os fatos naturais da vida aparecem como existindo anteriormente a qualquer outra coisa.

${ }^{16}$ STRATHERn, M. Reproducing the Future. Essays on Anthropology, Kinship and the New Reproductive Technologies. Manchester, Manchester University Press, 1992. 
Portanto, um parente do qual não se tem dúvida é aquele que está ao mesmo tempo relacionado pelo sangue e cujo relacionamento é reconhecido socialmente. Havendo um laço biológico, sempre haverá a questão de se este será seguido por um reconhecimento social ou não.

Voltando às noções manifestadas pelos entrevistados, podese considerar que a participação biológica do homem na reprodução, transmitindo seus genes, seu "sangue", representa o "fato natural" sobre o qual a paternidade é construída, mesmo que, posteriormente ao modelo construído, essa participação não venha a ser tida como o elemento principal ou o mais importante na experiência da paternidade. É como se o "fato natural da procriação" fosse considerado como a "base natural" sobre a qual a paternidade é construída, mas uma vez que essa construção é social, ela abre a possibilidade de a paternidade ser elaborada também somente através dos laços sociais.

Concluo este artigo considerando que o desejo de ter um filho "que seja seu" e a importância dada ao aspecto biológico da paternidade apontam para uma representação sobre a reprodução baseada na idéia de que é a reprodução biológica que estabelece as ligações afetivas e emocionais entre pais e filhos. Portanto, a reprodução biológica serve como modelo para o estabelecimento dessas ligações, como demonstram as declarações de que se pode amar um filho que "não é seu" "como se fosse seu". Assim, essas ligações podem ser estabelecidas com um filho adotivo (ou da esposa), e pode-se amá-lo "como se fosse seu", isto é, como se ama um filho biológico por princípio. Pode-se amá-lo segundo o modelo baseado no amor que se sente pelos "filhos verdadeiros", pode-se amá-lo "sem nenhuma diferença". Mas é a própria necessidade de negar essa diferença que marca sua presença nas representações sobre paternidade. 
Sonho do passado versus plano para o futuro

\section{Considerações finais}

Gênero apareceu informando as noções sobre esterilidade e desejo por filhos. Pois a esterilidade mostrou ser um problema que fere tanto a masculinidade quanto a feminilidade, mas de maneiras distintas. Pelo fato de comumente a esterilidade masculina estar associada à impotência, não conseguir ter filhos relaciona-se para os homens à sexualidade, e ameaça sua virilidade. Já para as mulheres, a esterilidade ameaça sua feminilidade porque as impede de cumprir sua vocação feminina "natural" de mãe. Assim, a esterilidade é um elemento que pode colocar, ainda que por vias distintas, tanto a masculinidade quanto a feminilidade em patamares mais baixos do gradiente de hierarquia de "mais ou menos" masculino/feminino.

Porém, há ainda outra distinção. Como a paternidade é concebida como um plano para o futuro, ela abriga a possibilidade de mudança desse plano, o que parece levar à idéia de que os homens superam (superariam) melhor que as mulheres o fato de não conseguirem ter filhos. Já a concepção da maternidade como a realização de uma essência feminina, informaria as noções de desespero das mulheres quando não conseguem ter filhos. Essas concepções também levam à percepção de que as mulheres desejam, mais que os homens, ter filhos, chegando mesmo a ficarem "obcecadas" por isso.

Estas distinções revelam como concepções sobre paternidade e maternidade encontram-se mediadas por diferentes atribuições de responsabilidade, de desejo e de possibilidades informadas por gênero. 